\title{
Effect of Reinforcements in the enhancement of Mechanical Properties: An Experimental Study
}

\author{
Gourav Kalra ${ }^{1}$, BikramJit Singh ${ }^{2}$ \\ 1,2 (Mechanical Engineering, MM University, Ambala, India)
}

\begin{abstract}
Aluminium alloy is an emerging material used in various applications of aerospace engineering, automobile engineering etc. As per industrial requirements, these materials may be get failed due to their mechanical properties like strength, hardness etc. Mechanical properties of these alloys can be improved with addition of reinforcements. In the present work, effect of these reinforcements on mechanical properties of AA1100 matrix hybrid composite have been investigated to study compressive strength, hardness. Composite were prepared at MMU, Mullana using Stir casting setup. It has been found that mechanical properties influenced by compositional parameters. Behavior analysis shows that compressive strength and hardness increases with increase in Si and Cu compositions.
\end{abstract}

Keywords: AA1100, Stir Casting, Reinforcements, Compressive strength, Hardness, UTM, Vickers hardness Machine.

\section{INTRODUCTION}

Demand for light weight, flexible, and eco friendly material is increasing widely in automobile, aerospace sectors etc. Aluminum is known by universal material due to its great strength to weight ratio, high stiffness, and great metallurgical property as well as high corrosion resistance etc. Although it has high strength to weight ratio and good mechanical properties still it cannot be used in automobile sector. To overcome this limitation we have to improve its mechanical properties and make it in suitable form which can be use in engineering applications. This can be obtained with the use of aluminum composite. Compressive strength and Hardness are the main responses that should be in suitable ranges fulfill industrial applications. There are many techniques which is use to fabricate these composites such as powder metallurgy, casting, spray deposition, etc. out of which casting is one of the best route to fabricate these composites.[1]

Further, it has been found that stir casting route is best fitted method to fabricate hybrid composite. [2,3] The importance of stir casting is its simplicity, flexibility and applicability to large scale production. $\mathrm{Si}, \mathrm{Cu}$ and $\mathrm{Mg}$ can be considered as reinforcements, due to their high strength, high aspect ratio and thermo-mechanic properties [4,5]. After the formation of hybrid composites specimens for mechanical testing have been tailored as per ASTM standard. Actual experimentations were done at MMU, Mullana in Metallurgical Lab. Whereas testing were carried out at CITKO (Chandigarh) Universal testing machine have been used to measured Compressive strengths whereas Vickers hardness tester has been used to calculate hardness.

\section{LITRATURE SURVEY}

Henri et al. (2014) had given an idea that $\mathrm{Si}, \mathrm{Cu}, \& \mathrm{Mg}$ in the powder form can be mixed for better improvement in aluminum alloys up to $1 \%$ to $14 \%, 2 \%$ to $5 \%$ to $10 \%$ respectively. And these reinforcement help to improve the mechanical properties like compressive strength, hardness, strength etc. also it improve the tribo-logical properties like wear etc. and microstructure [1]. Dwivedi et al. (2014) prepared an AA6082/SiC metal matrix composite with different size of reinforcements $(75 \mu \mathrm{m}, 50 \mu \mathrm{m}$ and $25 \mu \mathrm{m})$ by mechanical stir casting. Macrostructural analysis, tensile test, hardness test, impact test were performed to find out microstructure and mechanical properties of the metal matrix composites. Minimum porosity was observed for the $25 \mu \mathrm{m}$ of silicon carbide. The mechanical properties showed that the reduction of the size of $\mathrm{SiC}$ particles led to the improvement in tensile 
strength, hardness and toughness. It indicates that size of reinforcement is the effective factor influencing the mechanical properties.[6]

Sharma et al.(2013) described that stir casting for production of Aluminium-matrix composite and various process parameter of stir casting and Difficulties encountered in successful manufacturing of AMC by stir casting. Processing variables such as holding temperature, stirring speed, size of the impeller, and the position of the impeller in the melt are among the important factors to be considered in the production of cast metal matrix composites as these have an impact on mechanical properties. [7] Mathur et al. (2013) studied Effect of Process Parameter of Stir Casting on Metal Matrix Composites with Sic and $\mathrm{Cu}$.

Hardness of the composites found increased with increased grit size of SiC. Impact (Izod), tensile strength of the composites found increased with increased grit size of $\mathrm{SiC}$. The pouring temperature of $725^{\circ} \mathrm{C}$ gave the best optimum value of hardness, impact strength and ultimate tensile strength [8]Bhandare et al. (2013) prepared Aluminium Matrix Composite by Using Stir Casting Method For uniform dispersion of material blade angle should be $45^{\circ}$ or $60^{\circ} \&$ no of blade should be 4 .

For good wet ability we need to keep operating temperature at semisolid stage i.e. 630 for $\mathrm{Al}$ (6061). At full liquid condition it is difficult uniform distribution of the reinforcement in the molten metal. And Preheating of mould helps in reducing porosity as well as increases mechanical properties.[15]

Based on the literature survey ranges of composition of reinforcements have been discussed in table 1.

TABLE I: Range of parameter took by Authors

\begin{tabular}{|c|c|c|c|c|c|}
\hline Sr. & Authors & AA1100 & Si & $\mathbf{C u}$ & Mg \\
\hline 1 & $\begin{array}{l}\text { Henri, R.W., Loper, C. R., Rosenthal, P.C. } \\
\text { (2014) }\end{array}$ & $\begin{array}{ll}71 \% & \text { To } \\
97 \% & \end{array}$ & $\begin{array}{l}1 \% \text { to } \\
14 \%\end{array}$ & $2 \%$ to $5 \%$ & $4 \%$ to $10 \%$ \\
\hline 3 & $\begin{array}{l}\text { Kumar, R., Bhandare, G., Sonawane, P. } \\
\text { M. (2013) }\end{array}$ & NA & NA & $4.00 \%$ & NA \\
\hline 5 & John Gilbert Kaufman, Elwin L. Rooy, & $\begin{array}{l}72.5 \% \text { to } \\
89 \%\end{array}$ & $\begin{array}{l}5 \% \text { to } \\
12 \%\end{array}$ & 2 to $5.5 \%$ & $4 \%$ to $10 \%$ \\
\hline 7 & Bhaskar Chandra Kandpal & NA & NA & $2 \% 9.4 \%$ & $\begin{array}{ll}1.06 \% & \text { to } \\
3.13 \% & \end{array}$ \\
\hline 8 & SerajulHaque & NA & NA & $4.00 \%$ & NA \\
\hline 10 & M.J. STARINK, P. VAN MOURIK & NA & 19.1 & 1.3 & NA \\
\hline
\end{tabular}

\section{EXPERIMENTATION AND TESTING}

Aluminum hybrid composite has been fabricated by stir casting process. In which AA1100 was a base material whereas $\mathrm{Si}, \mathrm{Cu}$ and $\mathrm{Mg}$ were reinforcement. Execution of experiments been done as per orthogonal matrix which was generated in Mixture-DoE by Minitab software.

On the basis of literature $\mathrm{Si}, \mathrm{Cu}$ and $\mathrm{Mg}$ chose as reinforcement and AA1100 as base metal. AA1100 70\% to $90 \%, \mathrm{Si} 5 \%$ to $16 \%, \mathrm{Cu} 4 \%$ to $10 \%$ and for $\mathrm{Mg}$ was fixed to $2 \%$ and for process parameters stirring speed 400 rpm, stirring temperature $700^{\circ} \mathrm{C}$ and stirring time was 5 to 10 minutes. After the processing these parameters an experimental matrix has been formed as shown in table 3.2. These runs than executed on stir casting setup. 
IOSR Journal of Mechanical and Civil Engineering (IOSR-JMCE) e-ISSN: 2278-1684, p-ISSN: 2320-334X

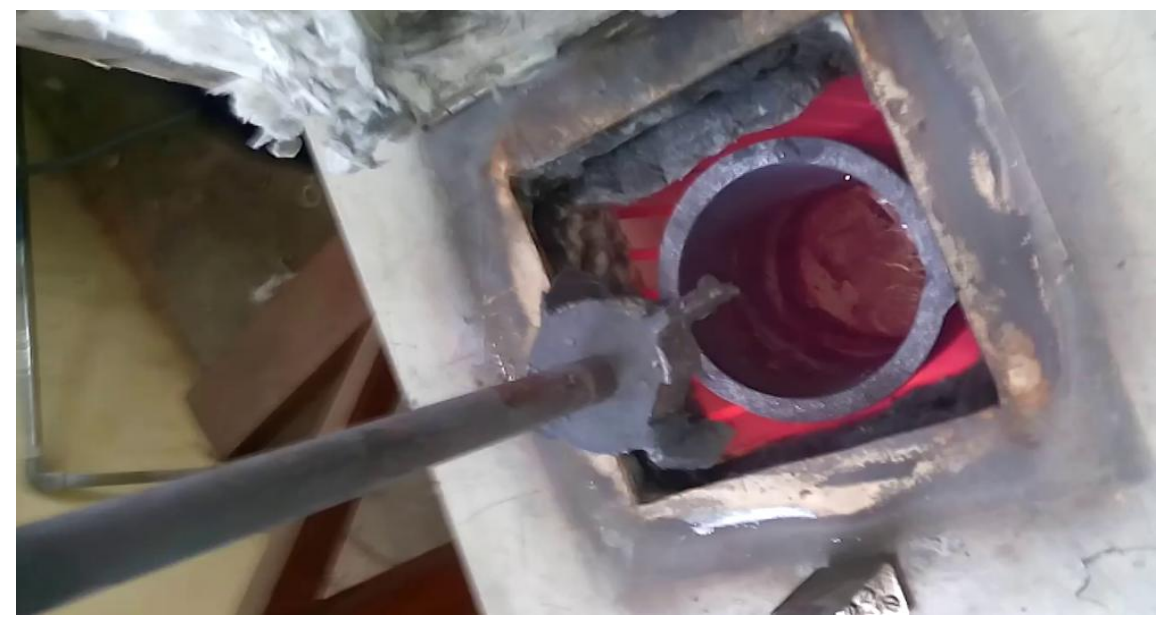

Fig. 1: Stir Casting Machine

\subsection{Mechanical Testing}

Specimens for testing were made with the help of lathe machine and specification of the specimens was as per guidelines which were given by CITKO, Chandigarh. Specimens for compressive strength test and hardness test as shown in fig.2.
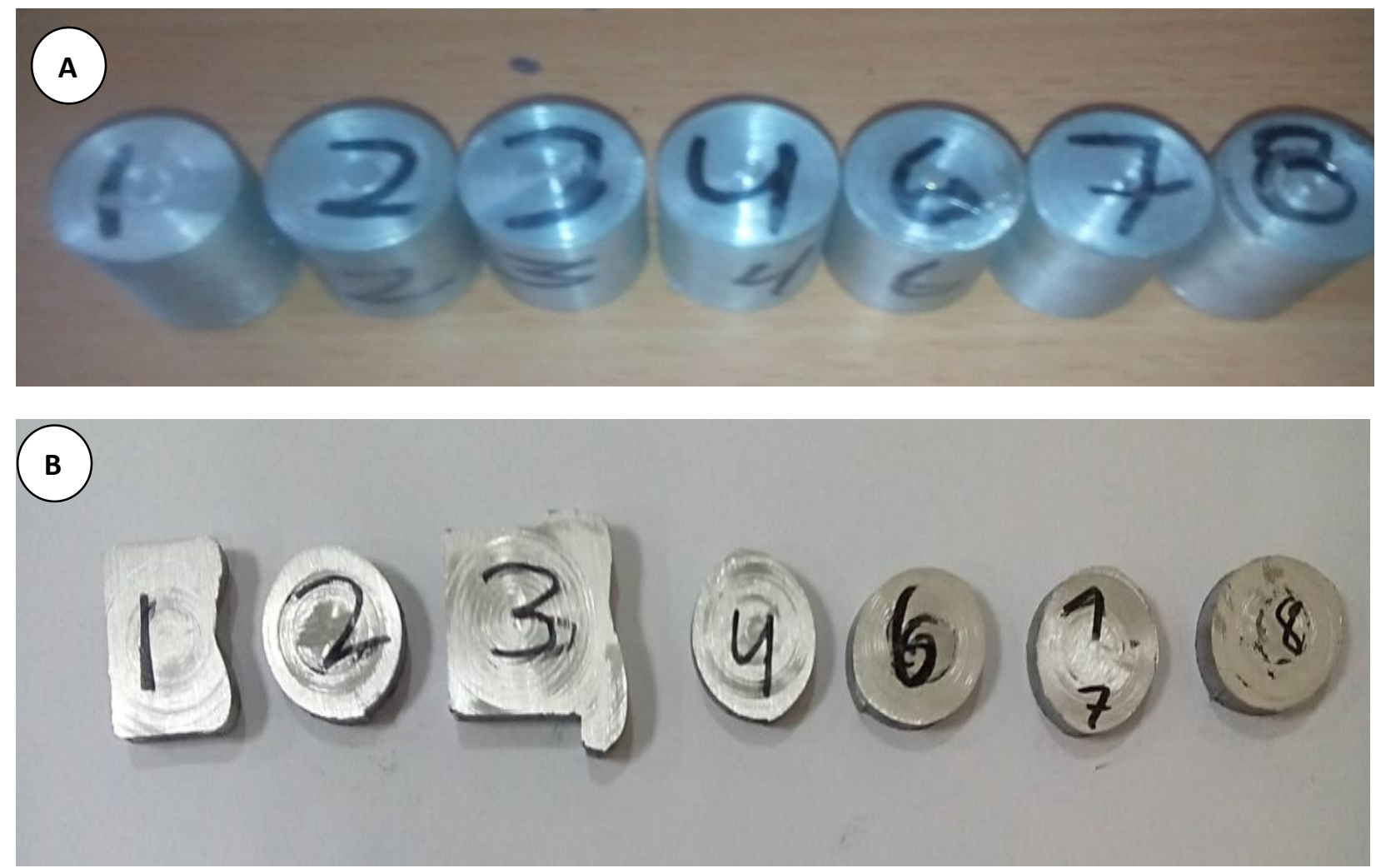

Fig. 2: Specimens for (A) Compressive strength test, (B) Hardness test 
IOSR Journal of Mechanical and Civil Engineering (IOSR-JMCE)

e-ISSN: 2278-1684, p-ISSN: 2320-334X

Compressive testing was carried out UTM and Hardness testing was carried on Vickers hardness tester. Testing was done at room temperature.

TABLE II. Test Results

\begin{tabular}{|c|c|c|c|c|c|c|c|}
\hline \multirow[b]{2}{*}{ Runs } & \multicolumn{4}{|c|}{ Compositional Parameters } & \multirow{2}{*}{$\begin{array}{c}\text { Process } \\
\text { Parameters } \\
\text { Stirring Time } \\
\text { (Mins) }\end{array}$} & \multicolumn{2}{|c|}{ Mechanical Properties } \\
\hline & $\begin{array}{c}\text { AA1100 } \\
(\%)\end{array}$ & Si (\%) & $\mathrm{Cu}(\%)$ & $\begin{array}{l}\mathrm{Mg} \\
(\%)\end{array}$ & & $\begin{array}{c}\text { Compressive } \\
\text { Strength (Mpa) }\end{array}$ & $\begin{array}{c}\text { Hardness } \\
\text { (HV) }\end{array}$ \\
\hline 1. & 0.83 & 0.05 & 0.1 & 0.02 & 10 & 334 & 85 \\
\hline 2. & 0.72 & 0.16 & 0.1 & 0.02 & 5 & 00 & 00 \\
\hline 3. & 0.79 & 0.13 & 0.06 & 0.02 & 5 & 210 & 50 \\
\hline 4. & 0.89 & 0.05 & 0.04 & 0.02 & 10 & 256 & 60 \\
\hline 5. & 0.8 & 0.11 & 0.07 & 0.02 & 5 & 242 & 64 \\
\hline 6. & 0.78 & 0.16 & 0.04 & 0.02 & 10 & 325 & 88 \\
\hline 7. & 0.77 & 0.13 & 0.08 & 0.02 & 10 & 00 & 00 \\
\hline 8. & 0.81 & 0.08 & 0.09 & 0.02 & 5 & 326 & 79 \\
\hline 9. & 0.79 & 0.13 & 0.06 & 0.02 & 10 & 215 & 56 \\
\hline 10. & 0.83 & 0.05 & 0.1 & 0.02 & 5 & 328 & 81 \\
\hline 11. & 0.8 & 0.11 & 0.07 & 0.02 & 10 & 250 & 72 \\
\hline 12. & 0.72 & 0.16 & 0.1 & 0.02 & 10 & 00 & 00 \\
\hline 13. & 0.77 & 0.13 & 0.08 & 0.02 & 10 & 00 & 00 \\
\hline 14. & 0.78 & 0.16 & 0.04 & 0.02 & 10 & 321 & 85 \\
\hline 15. & 0.89 & 0.05 & 0.04 & 0.02 & 5 & 253 & 58 \\
\hline 16. & 0.84 & 0.08 & 0.06 & 0.02 & 5 & 237 & 56 \\
\hline 17. & 0.81 & 0.08 & 0.09 & 0.02 & 10 & 333 & 88 \\
\hline 18. & 0.84 & 0.08 & 0.06 & 0.02 & 5 & 236 & 56 \\
\hline 19. & 0.89 & 0.05 & 0.04 & 0.02 & 5 & 251 & 56 \\
\hline 20. & 0.83 & 0.05 & 0.1 & 0.02 & 5 & 327 & 80 \\
\hline 21. & 0.89 & 0.05 & 0.04 & 0.02 & 10 & 258 & 63 \\
\hline 22. & 0.77 & 0.13 & 0.08 & 0.02 & 5 & 00 & 00 \\
\hline 23. & 0.78 & 0.16 & 0.04 & 0.02 & 5 & 313 & 80 \\
\hline 24. & 0.72 & 0.16 & 0.1 & 0.02 & 10 & 00 & 00 \\
\hline 25. & 0.81 & 0.08 & 0.09 & 0.02 & 5 & 322 & 76 \\
\hline 26. & 0.81 & 0.08 & 0.09 & 0.02 & 10 & 330 & 83 \\
\hline 27. & 0.79 & 0.13 & 0.06 & 0.02 & 10 & 217 & 55 \\
\hline 28. & 0.77 & 0.13 & 0.08 & 0.02 & 5 & 00 & 00 \\
\hline 29. & 0.72 & 0.16 & 0.1 & 0.02 & 5 & 00 & 00 \\
\hline 30. & 0.78 & 0.16 & 0.04 & 0.02 & 5 & 310 & 76 \\
\hline 31. & 0.8 & 0.11 & 0.07 & 0.02 & 10 & 252 & 71 \\
\hline 32. & 0.8 & 0.11 & 0.07 & 0.02 & 5 & 244 & 68 \\
\hline 33. & 0.83 & 0.05 & 0.1 & 0.02 & 10 & 336 & 86 \\
\hline 34. & 0.79 & 0.13 & 0.06 & 0.02 & 5 & 209 & 48 \\
\hline 35. & 0.84 & 0.08 & 0.06 & 0.02 & 5 & 245 & 72 \\
\hline 36. & 0.84 & 0.08 & 0.06 & 0.02 & 10 & 247 & 65 \\
\hline
\end{tabular}




\section{RESULT AND DISCUSSION}

Table II shows that on varying composition of reinforcements mechanical responses varies. Result for mechanical responses i.e. compressive strength and hardness are as shown in above figure. It have been found that with varying composition parameters a wide ranges of mechanical properties can be achieved as per industrial requirements. A graphical plot in between mechanical response value and sample no is as shown in table 3.3.

TABLE III. Graph showing variation in Compressive Strength and Hardness

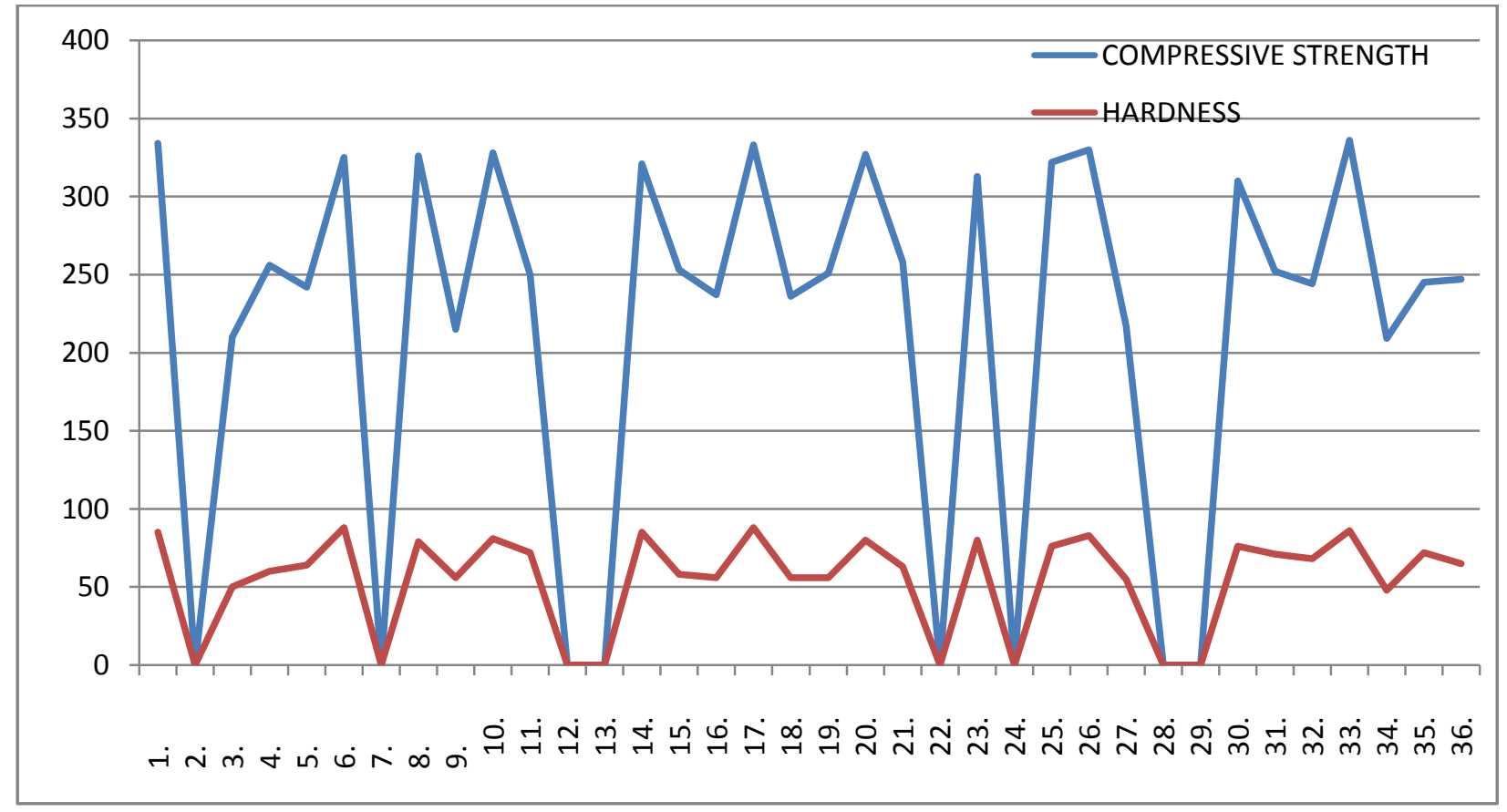

\section{CONCLUSION}

MMHC of AA1100 reinforced with $\mathrm{Si}, \mathrm{Cu}$ and $\mathrm{Mg}$ have been manufactured using stir casting process. Mechanical studies have been performed for casted components. UTM and Vickers hardness tester have been used to carried out mechanical studies Major conclusion that carried out during the invesigation of experimental study are as follows.

- Liquid metallurgy technique can be successfully adopted for fabrication of $\mathrm{Al} / \mathrm{Si} / \mathrm{Cu} / \mathrm{Mg}, \mathrm{As}$ the developed composite consistes of three particulate reinforcements.

- The hybrid composites $\mathrm{Al}-1100 / \mathrm{Si} / \mathrm{Cu} / \mathrm{Mg}$ were successfully produced by the stir casting process. Strings as well as particulate agglomerates were present as distinct micro structural features of the composite.

- $\mathrm{Al} / \mathrm{Si} / \mathrm{Cu} / \mathrm{Mg}$ Composite containing $5 \%$ of $\mathrm{Si}$ and $10 \%$ of $\mathrm{Cu}$ shows highest compressive strength and hardness.

- It has been concluded that with increase in the composition of $\mathrm{Si}$ and $\mathrm{Cu}$ mechanical properties decreases upto some level than it increases.

- The stress values sustained by all the composites specimens in compression tests during aproxipatly $30 \%$ reduction of their initial height.

- The presence of $\mathrm{Mg} 2 \%$ shows beneficiary effect on strength in aluminum cast composites by increasing the wetting, bonding strength.

- Compressive strength from $210 \mathrm{Mpa}$ to $334 \mathrm{Mpa}$ and hardness from 50HV to $81 \mathrm{HV}$ can be achieved with different combinations of parameters. 


\section{ACKNOWLEDGMENT}

I am great thankful to my guide Dr. BikaramJit Singh for encouraging me and support me throughout the work. I would like to thanks Mr. Ramsaran and Mr. Mukesh for their help and support in carrying out the experiments.

\section{REFERENCES}

[1] Henri, R.W., Loper, C. R., Rosenthal, P.C. (2014), "Principle of metal casting" Tata McGraw-hill education.

[2] Jokhio, M. H, Panhwar, M.I. and UNAR, M. A. (2011), "Manufacturing of AluminiumComposite Material Using Stir Casting Process" Mehran University research journal of engineering \& technology, Vol. 30, No. 1, pp. 53-64.

[3] Hashim J., Thesis (1999) "The Prduction of metal matrix composites using the stir casting technique" Dublin City University Ireland.

[4] Dwivedi, S.P., Gupta, B. and Chaudhary, D. (2013), "The Effect of Process Parameters on Mechanical Stir Casting Process" NIET Journal of Engineering \& Technology, Vol. 1, No. 2, pp. 1-7.

[5] Sarangi S., Kumar D. (2009), "Fabrication and Characterisation of Aluminium-Fly ash composite using stir Casting method" National Institute of Technology Rourkela.

[6] Dwivedi, S. P., Singh, S., Pali, H. S. (2014), "Macrostructure and Mechanical Properties of AA6082/SiC Composite Produced By Mechanical Stir Casting Process", International Conference of Advance Research and Innovation, Vol. 567

[7] Sharma, P., Chauhan, G., Sharma, N. (2013), "Production of AMC by stir casting - An Overview", International Journal of Contemporary Practices, pp. 23-46.

[8] Mathur S., Barnawal A. (2013), "Effect of Process Parameter of Stir Casting on Metal Matrix Composites" International Journal of Science and Research Vol. No. 12, pp. 395-398.

[9] Prabhu, S. B. (2006), "Influence of stirring speed and stirring time on distribution of particles in cast metal matrix composite", Journal of Materials Processing Technology, Vol. 171, pp. 268-273

[10] Sekar, K., Allesu, K. and Joseph, M. A. (2013), "Design of Stir Casting Machine”, American International journal of research in science, Technology, Engineering \& mathematics, ISSN 2328-3491, pp. 56-62.

[11] Kumar, R., Bhandare, G., Sonawane, P. M. (2013), "Preparation of Aluminium Matrix Composite by Using Stir Casting Method", International Journal of Engineering and Advanced Technology, Vol. 3, No. 2, pp. 61-65.

[12] Abdollahi, A., Alizadeh, A., Baharvandi, H. R. (2014), "Dry sliding tri-bologicalbehavior and mechanical properties of Al2024-5 wt. \% B4C nano-composite produced by mechanical milling and hot extrusion”, Materials and Design, Vol. 55, pp. 471-481.

[13] Sozhamannan, G. G., Prabu, S. B., V.S.K. Venkatagalapathy (2012), "Effect of Processing Parameters on Metal Matrix Composites: Stir Casting Process", Journal of Surface Engineered Materials and Advanced Technology, Vol. 2, pp. 11-15.

[14] Prabhu, S. B. (2006), "Influence of stirring speed and stirring time on distribution of particles in cast metal matrix composite", Journal of Materials Processing Technology, Vol. 171, pp. 268-273.

[15] Kumar, R., Bhandare, G., Sonawane, P. M. (2013), "Preparation of Aluminium Matrix Composite by Using Stir Casting Method", International Journal of Engineering and Advanced Technology, Vol. 3, No. 2, pp. 61-65.

[16] Natrajan,N., Vijayaranjan,S. and Rajendran,I.(2006), "Wear behavior of A356/25 SiCpalumunium metal composite sliding against automobile friction martial.” Wear, Vol.261, No. 7- 8, pp 812-822.

[17] Surappa M.K ,(2003), “Aluminum Matrix Composite Challenges and Opportunities” Sadhana Volume 28 part 1\&2 Feb/April 2003 pp319334

[18] Das. S.,(2004) "Devlopent of Aluminum Alloy Composites for Engineering pplications" Trans, Indian institute of Metals, Vol: 27 No 4 August 2004, PP 325-334.

[19] Singla, M. (2009), "Development of Aluminium Based Silicon Carbide Particulate Metal Matrix Composite", Journal of Minerals \& Materials Characterization \& Engineering, Vol. 8, No.6, pp. 455-467.

[20] ]Ibrahim I.A., Lavernia E.J., (1991), "Particulate reinforced metal matrix composites - a review", Journal of materials science, Vol. 26, pp. 1137- 1156.

[21] Rohatgi P.K. (2005), "Scatter and Statistical Analysis of Tensile Properties of Cast SiC Reinforced A359 Alloys", Materials Science and Engineering, Vol. 398, No. 1-2, pp. 1-14.

[22] Thangarasu, A., Mohankumar, R., Murugan, N. (2014), "Processing and characterization of AA6082/TiC composites by stir casting", Emerging Materials Research, pp. 1-7.

[23] Abdollahi, A., Alizadeh, A., Baharvandi, H. R. (2014), "Dry sliding tri-bologicalbehavior and mechanical properties of Al2024-5 wt. \% B4C nano-composite produced by mechanical milling and hot extrusion”, Materials and Design, Vol. 55, pp. $471-481$. 